\title{
Influence of Rice (Oryza sativa) Based System Diversification on Yield Attributes of Rice, Productivity, Water Economics, Uptake of Nutrients and Soil-Health
}

\author{
Vikas Jain* and H. S. Kushwaha \\ Department of Agronomy, Jawaharlal Nehru Krishi Vishwavidyalaya, \\ Jabalpur, Madhya Pradesh 482 004, India \\ *Corresponding author
}

A B S T R A C T

\begin{tabular}{l} 
K e y w o r d s \\
$\begin{array}{l}\text { Diversification, rice } \\
\text { equivalent yields } \\
\text { (REY), production } \\
\text { efficiency, water } \\
\text { productivity, } \\
\text { nutrient uptake and } \\
\text { soil-properties }\end{array}$ \\
Article Info \\
$\begin{array}{l}\text { Accepted: } \\
\text { 12 February } 2020 \\
\text { Available Online: } \\
\text { 10 March } 2020\end{array}$ \\
\hline
\end{tabular}

The experiment was conducted at Jabalpur (M.P.) for 2 consecutive years (2007-08 to 2008-09) to identify suitable diversified cropping systems to study productivity, water economics, mining of nutrients and soil improvement over existing rice-wheat and ricechickpea cropping system for Kymore Plateau and Satpura Hills agroclimatic zone. Between the 4 varieties of rice of different duration, Pro Agro 6444 topped in yield attributes like tillers/ $\mathrm{m}^{2}$ (434.6 to 434.9 ) and grains per panicles (155.7 to 156.7) along with grain $(6.25$ to $6.31 \mathrm{t} / \mathrm{ha})$ and straw yields $(9.38$ to $9.44 \mathrm{t} / \mathrm{ha})$. Among the $12 \mathrm{rice}-$ based cropping systems tested, Hy. rice-vegetable pea-sunflower topped for rice equivalent yields and production efficiency $(24.82 \mathrm{t} / \mathrm{ha}, 7.91 \mathrm{~kg} / \mathrm{ha} / \mathrm{day})$, followed by Hy rice-garlicmaize+cowpea fodder (22.02 t/ha, $6.79 \mathrm{~kg} / \mathrm{ha} /$ day) and Hy rice-potato-maize cob+fodder (19.02 t/ha.5.92 kg/ha/day) in chronological order. The consumptive use of water was found to be maximum (201.16 cm/ha) for Rice (Pusa Basmati-1) - Berseem (JB-5) fodder+Seed while water productivity was highest $(582.87 \mathrm{~kg} / \mathrm{ha} / \mathrm{cm})$ for Hy rice $(\mathrm{JRH}-5)$ - Vegatable pea (Arkel) -Sunflower (PSH-12). All newly proposed diversified intensive crop-sequences removed higher quantity of essential plant nutrient elements $(\mathrm{N}, \mathrm{P}, \mathrm{K})$ than existing crop-sequences and ther did not show remarkable change in physic-chemical properties of the soil over their parental status, when existing rice-wheat system exhibited significant reduction in organic and $\mathrm{N}$ contents of soil.

\section{Introduction}

In Kymore plateau and Satpura hills agroclimatic zone of Madhya Pradesh ricewheat cropping system is predominant under adequate irrigation water situation. Ricechickpea is also next prevalent cropping system in the areas having marginal scarcity of irrigation water. Generally, cultivation of both cereals i.e. rice and wheat in a sequence are costly and fertility exhaustive side by side they gain less monetary values. Growing of chickpea in place of wheat during Rabi season is being preferred by farmer because of its high market price, but low productivity again makes this effort futile. As a whole, cultivation of both rice and wheat crop in a sequence is costly, time consuming, energy 
exhaustive and tedious, besides their poor market value of the produce. Consequently, the socio-economic status of the farmers associated with rice based cropping system areas is quite low. Hence, there is an urgent need to intensify or diversify the prevailing cropping system for improving the productivity and profitability per unit area per year without jeopardizing the soil health from existing rice based cropping systems.

Crop diversification in India is generally viewed as a shift from traditionally grown less remunerative crops to more remunerative crops. Crop diversification has been recognized as an effective strategy for achieving the objective of food security, nutrition security, income growth, poverty alleviation, employment generation, judicious use of land and water resources, sustainable agricultural development and environmental improvement (Hedge et al., 2003).

During the last two decades, a shift was noticed in the consumption pattern, wherein the food consumption of cereals was declined in favour of a more varied and nutritious diet of a more varied and nutritious diet of fruits, vegetable, milk, fish, meat and poultry products. The crop diversification is also taking place due to governmental policies, thrust on some crop, market reforms, infrastructure development, government subsidies, higher profitability and stability in production also induces crop diversification. The purchase capacity of farmers needs to be increased from the present level.

Under such circumstances, the evaluation of suitable need based diversified cropping system by replacing existing ricewheat/chickpea system without degrading the soil-health is imperative to meet the domestic need of farmers. Hence, the present investigation has been made to evaluate the suitable diversified cropping system under existing agro-ecological and farming situation of the region.

\section{Materials and Methods}

The field experiment study was conducted during 2007-08 to 2008-09 under irrigated conditions in sandy clay loam soil at Research Farm, JNKVV, Jabalpur. The soil was initially slightly alkaline in reaction $(\mathrm{pH} 7.70)$ with normal EC $(0.48 \mathrm{dS} / \mathrm{m})$ and having medium OC contents $(0.68 \%)$. The available $\mathrm{N}, \mathrm{P}$ and $\mathrm{K}$ contents were medium (266 $\mathrm{kg} / \mathrm{ha}$ ), low (9.2 kg/ha) and medium (300 $\mathrm{kg} / \mathrm{ha}$ ), respectively. The field experiment consisted of 12 crop-sequences arranged in randomized block design with 4 replications and detail of crop-sequences is given in Table 1,2 and 3.

The agro-techniques for all crops were followed as per recommended practices and need of concerned crop in different cropsequences. The yield data of all crops were recorded from 2007-08 to 2008-09 and were pooled as differences between the year were not significant. Data on grain yields of individual crop were used to determine the combined yield of entire cropping system as rice equivalent yield (REY) with the help of existing market prices and yield realized from each crop. Production efficiency was worked out by dividing the REY with total duration (days) of all crop components.

Consumptive use of water (CUW) and water productivity was worked out on the basis of formula suggested by Dastane, 1972. The soil parameters viz. $\mathrm{pH}, \mathrm{EC}$, organic carbon, available N,P and $\mathrm{K}$ were estimated as per standard procedures in the beginning of the experiment. The uptake of N,P and $\mathrm{K}$ was analyzed for all the crops in the system and summed up to calculate the total uptake of the system. 


\section{Results and Discussion}

\section{Yield and yield attributing characters}

Rice cultivation was the only possibility under existing agro-climatic conditions of the locality in kharif season therefore option of diversifying crop components was remained limited upto other seasons i.e. rabi and zaid. The average number of effective tillers $/ \mathrm{m}^{2}$ significantly varied among different rice varieties in which Pro-Agro 6444 was significantly on top (434.6 to 434.9) position amongst all. Based upon 2 year pooled data, variety Pro-Agro 6444 had maximum number of grains per panicle (155.7 to 156.1) followed by JRH-5 (151.9 to 154.2), Pusa Basmati-1 (132.0) and Kranti (128.6 to 128.8) in descending order. But variation between Pro-Agro 6444 and JRH-5 was not identical. Variety JRH-5 led to record the maximum weight of panicle ranging from 4.03 to $4.18 \mathrm{~g}$ followed by Pro-Agro 6444 (4.05 g), Kranti (3.66 to $3.68 \mathrm{~g}$ ) and Pusa Basmati-1 (3.28 g), but variations among 3 former varieties were not significant. Variety Kranti had the highest test weight (28.4 to $28.5 \mathrm{~g}$ ) closely followed by JRH-5 (26.4 to $26.9 \mathrm{~g}$ ). The next best variety was Pro-Agro 6444 (25.4 to $25.9 \mathrm{~g}$ ) in this regard, which was at par to JRH-5 as well as Pusa Basmati-1 (24.7 g) for this character.

It is evident from the results given in Table 1 that grain yields of both rice hybrids were higher under newly tested crop-sequences than the yields of existing rice cv. Kranti during Kharif season while rice hybrid ProAgro 6444 yielded more grain yield (6.25 to $6.31 \mathrm{t} / \mathrm{ha}$ ) than hybrid JRH-5. Pusa Basmati-1 produced significantly minimum grain yield (37.85 q/ha) among all varieties. Variety Pro Agro 6444 significantly topped in straw yields (93.77 to $94.43 \mathrm{q} / \mathrm{ha}$ ) closely followed by Kranti ( 87.52 to 89.63 q/ha).The next best variety was hybrid JRH -5 (84.07 to 86.99 q/ha). Like grain yields, Pusa Basmati-1 again produced significantly the lowest straw yields (60.78 q/ha) among all varieties. Based on two years data the mean, HI value was maximum (40.01 to $40.06 \%$ ) with hybrid ProAgro 6444 closely followed by hybrid JRH -5 (39.68 to $39.94 \%)$. The next best variety was Pusa Basmati-1 (38.37\%), which was at par to Kranti (37.97 to $38.09 \%$ ) with regard to HI.

\section{System productivity}

While considering the REYs of croppingsystem as a whole, Hy. rice- vegetable peasunflower system topped for REYs (24.82 q/ha) among all crop-sequences mainly due to top REY of vegetable pea during Rabi along with considering good REYs of Hy. rice in Kharif and sunflower in summer season. The next best crop-sequence was Hy. rice-garlicmaize+cowpea (fodder) with regard to REYs $(22.02 \mathrm{q} / \mathrm{ha}$ ) mainly due to the higher REYs in Kharif rice and Rabi garlic.

All intensive cropping-system having 300\% cropping intensity significantly led to record higher REYs, ranging from $15.41 \mathrm{q} / \mathrm{ha}$ to $24.81 \mathrm{q} / \mathrm{ha}$, over both existing cropping sequences having $200 \%$ cropping intensity, mainly because of inclusion of summer crops in succession to previous crops without declining the REYs of Kharif and Rabi crops . Exceptionally, one diversified cropping system, $\mathrm{T}_{4}$-rice-berseem (fodder and seed) having 200\% cropping system also led to record significantly higher REYs (16.47 q/ha) than both existing cropping systems as well as some intensive cropping systems viz. ricegobhi sarson-maize cob+fodder, rice-gobhi sarson-groundnut+maize and rice-gobhi sarson-okra, because of remarkable higher REYs of berseem (fodder and seed) and scented rice (received premium price in market). Several researchers have also reported heterogeneity in production of potential varying crop-sequences from different agro-production systems (Chitle et 
al., 2011; Narkhede, et al., 2011; Kumar, et al., 2012 ; Kachroo, et al., 2014 and Baishya, et al., 2016).

\section{Production efficiency}

Among different crop-sequences tested, Hy rice JRH-5-vegetalbe pea- sunflower markedly led to register the highest production efficiency $(79.09 \mathrm{~kg} / \mathrm{ha} /$ day $)$ on account of maximum productivity of vegetable pea during Rabi season, besides comparable yields of Hy rice-JRH-5 in Kharif and sunflower in summer season. Thus this crop sequence produced maximum REY $(24.82 \mathrm{t} / \mathrm{ha})$. The crop duration for this sequence was lesser than many intensive crop sequences, which attributed to maximum production efficiency of this crop sequence.

The next best crop-sequences were hy. ricegarlic- maize+cowpea (fodder) with production efficiency of $(67.97 \mathrm{~kg} / \mathrm{ha} /$ day $)$ closely followed by Hy rice-potato-maize for cob (59.22 kg/ha/day) and Hy. rice-potatogroundnut $(59.20 \mathrm{~kg} / \mathrm{ha} /$ day $)$. The relatively high REY from garlic and potato crops during Rabi season and inclusion of maize+cowpea (fodder), groundnut and maize for cob during summer, respectively under these three cropping systems resulted in to such superiority with regard to production efficiency.

Remaining diversified intensive crop sequences led to record production efficiency ranging from 44.06 to $57.19 \mathrm{~kg} / \mathrm{ha} / \mathrm{day}$, which were higher than existing cropping systems $\mathrm{viz}$, rice -wheat $(43.98 \mathrm{~kg} / \mathrm{ha} /$ day $)$ and rice chickpea $(38.75 \mathrm{~kg} / \mathrm{ha} /$ day) systems. Berseem being a high yielding crop during Rabi season in succession to scented rice cv. Pusa Basmati-1 having high market value under scented rice Pusa Basmati -1 - berseem fodder + seed system led to record handsome production efficiency of $54.96 \mathrm{~kg} / \mathrm{ha} /$ day. It is remarkable here that replacement of wheat or chickpea by substituting berseem crop for fodder production alongwith seed production gave higher production efficiency than existing cropping systems. It gave an idea to belief that diversification of traditional crop with other high value crop has an opportunity to enhance the productivity and production efficiency of cropping system. Similar high values of production efficiencies with the inclusion of high yielding crops under diversified intensive cropping systems have been also reported by several other workers from the studies made under varying agroclimatic conditions (Paiboonrath et al., 2001; Adiswaranto et al., 2002; and Singh et al., 2016).

\section{Consumptive use of water and water productivity}

The total productivity of Hy rice - vegetable pea - sunflower was maximum in terms of REY (24.82 t/ha), with the CUW of 170.28 $\mathrm{cm} / \mathrm{ha}$. Maximum rice equivalent yield from its one component crop vegetable pea (15.52 t/ha) with quite low CUW mainly contributed to maximum water productivity $(582.87$ $\mathrm{kg} / \mathrm{ha} / \mathrm{cm}$ ) under this system. Similarly, the REYs of Hy rice-gobhi sarson-okra (16.05 t/ha) was mainly contributed with the higher yield of okra grown during summer season with the optimum CUW, which attributed to considerably quite good water productivity (388.05 kg/ha/cm).

Another cropping sequence viz. Hy ricegarlic-maize+cowpea (fodder) had good REY (22.02 t/ha) in which garlic grown in Rabi season had contributed much through higher REY. Inclusion of groundnut or maize during summer season as well as potato or onion during Rabi season in different rice-based cropping systems helped to achieve the considerable water productivity of different diversified intensive cropping system. 
Inclusion of potato in rice based cropping system in place of wheat during Rabi season in succession to rice produced quite higher REY (190.15 to $201.00 \mathrm{q} / \mathrm{ha}$ ) than rice wheat (117.43 q/ha). The CUW of potato was quite lesser than CUW for wheat. Consequently, rice - potato- maize cob $(374.83 \mathrm{~kg} / \mathrm{ha} / \mathrm{cm})$ and rice-potato-groundnut (363.63 kg/ha/cm) crop sequences led to record higher water productivity than predominant existing rice- wheat system. Hy rice - onion- green gram produced REY of 186.38q/ha with CUW of $191.98 \mathrm{~cm} / \mathrm{ha}$, which was higher than several crop sequences, but its water productivity was $337.32 \mathrm{~kg} / \mathrm{ha} / \mathrm{cm}$.

It is confirmed from the results that scented rice - berseem fodder + seed system had handsome REY of $164.61 \mathrm{q} / \mathrm{ha}$, but its water productivity was minimum (165.42 $\mathrm{kg} / \mathrm{ha} / \mathrm{cm})$. The CUW of berseem was maximum (96.76 cm/ha) among all Rabi crops, but yield advantages in terms of REY did not increase proportionately to its CUW.

The rice-berseem was higher yielder than both existing cropping systems, but it was more water exhaustive. These results are in close conformity with the findings of several workers with regard to water productivity of different crop -sequences under varying farming situations (Singh et al., 2001; Singh et al., 2008; Chitale et al., 2011; and Narkhede, et al., 2011).

\section{Uptake of nutrients}

It is evident from the data given in Table 3 that all newly proposed diversified intensive crop-sequences (Treatments $\mathrm{T}_{3}$ to $\mathrm{T}_{12}$ ) removed higher quantity of essential plant nutrient elements $(\mathrm{N}, \mathrm{P}, \mathrm{K})$ than existing cropsequences (rice-wheat and rice-chickpea) of the locality.
As regards removal of $\mathrm{N}$ uptake by crops of a particular crop sequence as a whole, all intensive crop-sequences led to remove greater $\mathrm{N}$ than both existing crop-sequences. Hy rice-potato-maize cob system removed the highest quantity of $\mathrm{N}(432.7 \mathrm{~kg} / \mathrm{ha})$ within a year among all crop-sequences tested. All the three crops of this system have ability to respond high dose of $\mathrm{N}$ application; hence the $\mathrm{N}$ removal was maximum with it. The next $\mathrm{N}$ exhaustive crop-sequence in descending order were Hy rice-marigold-maize $(396.2 \mathrm{~kg} / \mathrm{ha})$ and scented rice-berseem (393.2 kg/ha), which were at par.

Remaining diversified intensive cropsequences recorded $\mathrm{N}$ ranging from 171.85 to $302.3 \mathrm{~kg} / \mathrm{ha}$ which were higher than ricechickpea (115.25 kg/ha) system. Another ricewheat existing cropping system removed $205.30 \mathrm{~kg} / \mathrm{ha}$ which were higher than Hy ricegobhi sarson-okra system. The results are in close conformity with the findings of Khanda, et al., (2005), Sharma and Sharma (2002); Channabasavanna, et al., (2002); Sharma et al., (2008) and Baishya et al., (2016).

While considering uptake of $\mathrm{P}$, cropping system as a whole Hy rice-potato-maize system was again on top with the removal of $78.4 \mathrm{~kg} \mathrm{P} /$ ha but removal of $\mathrm{P}$ was very close to it under Hy rice-gobhi sarsongroundnut+maize and $\mathrm{Hy}$ rice-marigoldmaize(Chitale et al., 2011). Other cropping sequences led to record lesser depletion of $\mathrm{P}$ within a year than above mentioned cropsequences, mainly due to deviations in productivity of crops and $\mathrm{P}$ requirement of crops accommodated in different cropping systems.

The uptake pattern of $\mathrm{K}$ followed the same trend as to uptake of $\mathrm{N}$ by different crop sequences depending on the nature of crop and total productivity. 
Table.1 Yield attributing character and yield of rice under different rice-based cropping systems (pooled data of 2 years)

\begin{tabular}{|c|c|c|c|c|c|c|c|}
\hline Crop sequence & $\begin{array}{l}\text { Effective } \\
\text { tillers/ } \mathbf{m}^{2}\end{array}$ & $\begin{array}{l}\text { Grains/ } \\
\text { panicle }\end{array}$ & $\begin{array}{l}\text { Weight of } \\
\text { panicle (g) }\end{array}$ & $\begin{array}{c}\text { Test } \\
\text { weight }(g)\end{array}$ & $\begin{array}{c}\text { Grain yield } \\
\text { (t/ha) }\end{array}$ & $\begin{array}{c}\text { Straw Yield } \\
\text { (t/ha) }\end{array}$ & HI \\
\hline Rice (Kranti) - Wheat (GW-273) & 335.1 & 128.6 & 3.66 & 28.4 & 5.39 & 8.75 & 38.09 \\
\hline Rice (Kranti) - Chickpea (JG-322) & 334.3 & 128.8 & 3.68 & 28.5 & 5.49 & 8.96 & 37.97 \\
\hline $\begin{array}{l}\text { Hy rice (Pro Agro 6444) - Onion (Pusa } \\
\text { red) - Green gram (Pusa Vishal) G+R }\end{array}$ & 434.9 & 155.7 & 4.05 & 25.4 & 6.25 & 9.38 & 40.01 \\
\hline $\begin{array}{l}\text { Rice (Pusa Basmati-1) - Berseem } \\
\text { (JB-5) fodder+Seed }\end{array}$ & 299.3 & 132.0 & 3.28 & 24.7 & 3.79 & 6.08 & 38.37 \\
\hline $\begin{array}{l}\text { Hy rice (JRH-5) - Potato (Kufri Sinduri) } \\
\text {-Maize (JM-12) cob + fodder }\end{array}$ & 346.7 & 152.0 & 4.08 & 26.8 & 5.56 & 8.41 & 39.80 \\
\hline $\begin{array}{l}\text { Hy rice (JRH-5)- Gobhi sarson (Terri } \\
\text { Uttam) - Maize (JM-12) cob + fodder }\end{array}$ & 347.3 & 152.7 & 4.11 & 26.8 & 5.61 & 8.51 & 39.72 \\
\hline $\begin{array}{l}\text { Hy rice (JRH-5) - Vegatable pea } \\
\text { (Arkel) }- \text { Sunflower (PSH-12) }\end{array}$ & 346.5 & 154.2 & 4.17 & 26.9 & 5.62 & 8.55 & 39.74 \\
\hline $\begin{array}{l}\text { Hy rice (JRH-5) - Potato (Kufri Sinduri) } \\
\text {-Groundnut (Jyoti) }\end{array}$ & 346.8 & 153.5 & 4.03 & 26.9 & 5.71 & 8.59 & 39.94 \\
\hline $\begin{array}{l}\text { Hy rice (JRH-5) - Gobhi sarson (Terri } \\
\text { Uttam) - Groundnut (Jyoti) + Maize } \\
\text { (JM-12) 4:2 row }\end{array}$ & 347.0 & 151.9 & 4.09 & 26.7 & 5.66 & 8.61 & 39.84 \\
\hline $\begin{array}{l}\text { Hy rice (JRH-5) - Gobhi sarson (Terri } \\
\text { Uttam) - Okra (Parbhani Kranti) }\end{array}$ & 346.8 & 153.9 & 4.18 & 26.9 & 5.71 & 8.70 & 39.61 \\
\hline $\begin{array}{l}\text { Hy rice (JRH-5) - Garlic (G-41) - Maize } \\
(\text { JM-12) + Cowpea (Local) 4:2 row }\end{array}$ & 347.0 & 154.1 & 4.15 & 26.6 & 5.70 & 8.63 & 39.78 \\
\hline $\begin{array}{l}\text { Hy rice (Pro Agro 6444) - Marigold } \\
\text { (African Giant) - Maize (JM-12) cob + } \\
\text { fodder }\end{array}$ & 434.6 & 156.1 & 4.05 & 25.9 & 6.31 & 9.44 & 40.06 \\
\hline SEm \pm & 26.2 & 1.08 & 0.20 & 0.61 & 0.05 & 0.14 & 0.36 \\
\hline $\mathrm{CD}(\mathrm{P}=\mathbf{0 . 0 5})$ & 75.9 & 3.06 & 0.59 & 2.0 & 0.14 & 0.43 & 1.07 \\
\hline
\end{tabular}


Table 2.Effect of different rice-based cropping systems on REY (t/ha), Production efficiency (kg/ha/day), consumptive use of water $(\mathrm{cm} / \mathrm{ha})$ and water productivity $(\mathrm{kg} / \mathrm{ha} / \mathrm{cm})$

\begin{tabular}{|c|c|c|c|c|c|c|c|c|c|c|c|c|}
\hline \multirow[t]{2}{*}{ Crop sequence } & \multicolumn{3}{|c|}{ REY (t/ha) } & \multicolumn{3}{|c|}{$\begin{array}{c}\text { Production efficiency } \\
\text { (kg/ha/day) }\end{array}$} & \multicolumn{3}{|c|}{$\begin{array}{l}\text { consumptive use of water } \\
(\mathrm{cm} / \mathrm{ha})\end{array}$} & \multicolumn{3}{|c|}{ Water productivity $(\mathrm{kg} / \mathrm{ha} / \mathrm{cm})$} \\
\hline & $2007-08$ & 2008-09 & pooled & $2007-08$ & 2008-09 & pooled & $2007-08$ & 2008-09 & pooled & $2007-08$ & 2008-09 & pooled \\
\hline Rice (Kranti) - Wheat (GW-273) & 11.73 & 11.76 & 11.74 & 4.43 & 4.37 & 4.40 & 152.71 & 164.53 & 158.62 & 180.38 & 199.14 & 189.76 \\
\hline Rice (Kranti) - Chickpea (JG-322) & 9.64 & 9.01 & 9.32 & 3.95 & 3.80 & 3.88 & 123.90 & 126.73 & 125.32 & 251.91 & 230.63 & 241.27 \\
\hline $\begin{array}{l}\text { Hy rice (Pro Agro 6444) - Onion } \\
\text { (Pusa red) - Green gram (Pusa } \\
\text { Vishal) G+R }\end{array}$ & 18.22 & 19.05 & 18.64 & 5.52 & 5.92 & 5.72 & 192.47 & 191.48 & 191.98 & 328.27 & 346.38 & 337.32 \\
\hline $\begin{array}{l}\text { Rice (Pusa Basmati-1) - Berseem (JB- } \\
\text { 5) fodder+Seed }\end{array}$ & 17.29 & 15.65 & 16.47 & 5.71 & 5.29 & 5.50 & 204.84 & 197.47 & 201.16 & 169.45 & 161.39 & 165.42 \\
\hline $\begin{array}{llll}\text { Hy rice } & \text { (JRH-5) - Potato (Kufri } \\
\text { Sinduri) } & \text {-Maize } & \text { (JM-12) cob + } \\
\text { fodder } & & & \end{array}$ & 21.29 & 16.74 & 19.02 & 6.58 & 5.27 & 5.92 & 186.55 & 177.74 & 182.15 & 411.54 & 338.12 & 374.83 \\
\hline $\begin{array}{l}\text { Hy rice (JRH-5)- Gobhi sarson (Terri } \\
\text { Uttam) - Maize (JM-12) cob + } \\
\text { fodder }\end{array}$ & 14.80 & 12.90 & 13.85 & 4.58 & 4.23 & 4.41 & 161.17 & 153.63 & 157.40 & 384.06 & 348.86 & 366.46 \\
\hline $\begin{array}{l}\text { Hy rice (JRH-5) - Vegatable pea } \\
\text { (Arkel) -Sunflower (PSH-12) }\end{array}$ & 28.85 & 20.78 & 24.82 & 8.92 & 6.90 & 7.91 & 173.53 & 167.03 & 170.28 & 711.92 & 453.82 & 582.87 \\
\hline $\begin{array}{l}\text { Hy rice (JRH-5) - Potato (Kufri } \\
\text { Sinduri) -Groundnut (Jyoti) }\end{array}$ & 23.83 & 16.37 & 20.10 & 6.97 & 4.87 & 5.92 & 202.39 & 191.8 & 197.10 & 420.24 & 307.02 & 363.63 \\
\hline $\begin{array}{l}\text { Hy rice (JRH-5) - Gobhi sarson } \\
\text { (Terri Uttam) - Groundnut (Jyoti) + } \\
\text { Maize (JM-12) 4:2 row }\end{array}$ & 17.56 & 13.26 & 15.41 & 5.13 & 4.04 & 4.59 & 175.66 & 168.01 & 171.84 & 412.54 & 350.73 & 381.64 \\
\hline $\begin{array}{l}\text { Hy rice (JRH-5) - Gobhi sarson } \\
\text { (Terri Uttam) - Okra (Parbhani } \\
\text { Kranti) }\end{array}$ & 18.11 & 14.00 & 16.05 & 5.16 & 4.09 & 4.63 & 171.66 & 164.01 & 167.84 & 420.57 & 355.52 & 388.05 \\
\hline $\begin{array}{l}\text { Hy rice (JRH-5) - Garlic (G-41) - } \\
\text { Maize (JM-12) + Cowpea (Local) } \\
\text { 4:2 row }\end{array}$ & 23.58 & 20.47 & 22.02 & 7.17 & 6.42 & 6.79 & 198.29 & 185.18 & 191.74 & 394.68 & 370.18 & 382.43 \\
\hline $\begin{array}{l}\text { Hy rice (Pro Agro 6444) - Marigold } \\
\text { (African Giant) - Maize (JM-12) cob } \\
\text { + fodder }\end{array}$ & 17.23 & 16.35 & 16.79 & 5.40 & 5.31 & 5.35 & 186.50 & 181.55 & 184.03 & 338.42 & 337.48 & 337.95 \\
\hline SEm \pm & 0.44 & 0.70 & 0.58 & 0.21 & 0.39 & 0.30 & 1.17 & 2.11 & 1.64 & 6.87 & 4.35 & 5.61 \\
\hline $\mathrm{CD}(\mathrm{P}=0.05)$ & 1.32 & 2.01 & 1.70 & 0.60 & 1.11 & 0.86 & 3.36 & 6.05 & 4.70 & 19.10 & 12.59 & 16.13 \\
\hline
\end{tabular}


Table 3.Effect of different rice-based cropping systems on mean total uptake of nutrients (2 years) and changes in chemical properties of soil over initial status at the end of 2008-09

\begin{tabular}{|c|c|c|c|c|c|c|c|c|c|}
\hline \multirow[t]{2}{*}{ Crop sequence } & \multicolumn{3}{|c|}{ Uptake (kg/ha) } & \multirow[t]{2}{*}{ Soil pH } & \multirow{2}{*}{$\begin{array}{l}\text { E.C. } \\
(\mathbf{d S} / \mathbf{m})\end{array}$} & \multirow{2}{*}{$\begin{array}{l}\text { O.C. } \\
(\mathbf{g} / \mathrm{kg})\end{array}$} & \multicolumn{3}{|c|}{ Available nutrients (kg/ha) } \\
\hline & $\mathrm{N}$ & $\mathrm{P}$ & $\mathrm{K}$ & & & & $\mathrm{N}$ & $\mathrm{P}$ & $\mathrm{K}$ \\
\hline Initial & - & - & - & 7.70 & 0.48 & 6.8 & 266 & 9.2 & 300 \\
\hline Rice (Kranti) - Wheat (GW-273) & 205.3 & 44.3 & 58.9 & 7.65 & 0.48 & 5.9 & 246.2 & 9.0 & 291.4 \\
\hline Rice (Kranti) - Chickpea (JG-322) & 115.3 & 31.9 & 59.9 & 7.65 & 0.50 & 6.9 & 271.3 & 9.2 & 295.2 \\
\hline $\begin{array}{l}\text { Hy rice (Pro Agro 6444) - Onion (Pusa } \\
\text { red) - Green gram (Pusa Vishal) G+R }\end{array}$ & 259.2 & 48.7 & 20.9 & 7.70 & 0.54 & 7.0 & 284.2 & 9.1 & 297.6 \\
\hline $\begin{array}{l}\text { Rice (Pusa Basmati-1) - Berseem (JB-5) } \\
\text { fodder+Seed }\end{array}$ & 392.9 & 51.8 & 67.5 & 7.75 & 0.50 & 6.8 & 262.2 & 9.0 & 282.4 \\
\hline $\begin{array}{l}\text { Hy rice (JRH-5) - Potato (Kufri Sinduri) } \\
\text {-Maize (JM-12) cob + fodder }\end{array}$ & 432.7 & 78.4 & 148.9 & 7.75 & 0.52 & 6.3 & 252.5 & 8.8 & 278.2 \\
\hline $\begin{array}{l}\text { Hy rice (JRH-5)- Gobhi sarson (Terri } \\
\text { Uttam) - Maize (JM-12) cob + fodder }\end{array}$ & 359.4 & 64.8 & 08.9 & 7.70 & 0.52 & 6.6 & 254.2 & 8.8 & 282.4 \\
\hline $\begin{array}{l}\text { Hy rice (JRH-5) - Vegatable pea } \\
\text { (Arkel) -Sunflower (PSH-12) }\end{array}$ & 198.7 & 45.8 & 84.5 & 7.70 & 0.56 & 7.0 & 276.7 & 9.5 & 292.5 \\
\hline $\begin{array}{l}\text { Hy rice (JRH-5) - Potato (Kufri Sinduri) } \\
\text {-Groundnut (Jyoti) }\end{array}$ & 232.4 & 53.8 & 71.9 & 7.80 & 0.54 & 6.9 & 268.3 & 9.1 & 290.4 \\
\hline $\begin{array}{l}\text { Hy rice (JRH-5) - Gobhi sarson (Terri } \\
\text { Uttam) - Groundnut (Jyoti) + Maize } \\
\text { (JM-12) 4:2 row }\end{array}$ & 302.3 & 74.8 & 62.4 & 7.70 & 0.54 & 7.0 & 263.5 & 9.2 & 289.1 \\
\hline $\begin{array}{l}\text { Hy rice (JRH-5) - Gobhi sarson (Terri } \\
\text { Uttam) - Okra (Parbhani Kranti) }\end{array}$ & 171.8 & 38.8 & 98.6 & 7.70 & 0.52 & 6.9 & 274.4 & 9.2 & 294.4 \\
\hline $\begin{array}{l}\text { Hy rice (JRH-5) - Garlic (G-41) - Maize } \\
(\text { JM-12) + Cowpea (Local) 4:2 row }\end{array}$ & 317.7 & 57.6 & 68.9 & 7.59 & 0.47 & 6.9 & 291.2 & 9.0 & 287.8 \\
\hline $\begin{array}{l}\text { Hy rice (Pro Agro 6444) - Marigold } \\
\text { (African Giant) - Maize (JM-12) cob + } \\
\text { fodder }\end{array}$ & 396.1 & 71.9 & 30.8 & 7.31 & 0.49 & 7.1 & 286.2 & 9.0 & 294.7 \\
\hline SEm \pm & 4.81 & 2.97 & 6.87 & 0.12 & 0.12 & 0.38 & 2.77 & 0.21 & 5.89 \\
\hline $\mathrm{CD}(\mathrm{P}=\mathbf{0 . 0 5})$ & 14.8 & 8.45 & 21.4 & NS & NS & 1.09 & 8.65 & NS & 16.84 \\
\hline
\end{tabular}




\section{Changes in soil-properties}

Truely the present investigation represents the status of soil-properties at the end of third crop cycles under different crop-sequences. The present 2 year continuous studies have been started without changing the soil site and treatments, which were started one year earlier. In the very beginning of the experiment, parental status of soil properties viz. $\mathrm{pH}, \mathrm{EC}, \mathrm{OC}$ contents and available nutrients $(\mathrm{N}, \mathrm{P}, \mathrm{K})$ contents were recorded.

Therefore, several of the total crop-sequences had exhibited their influence by signaling a few marginal changes in the soil-properties (Table 3). In general, no significant variation in the values of $\mathrm{pH}$ and $\mathrm{EC}$ over their initial status were observed due to different treatments but OC contents of soil showed significant variation due to some cropsequence over it's inititial status (Chitale et al., 2011 and Baishya et al., 2016). The negative balance of OC contents was maximum with existing rice-wheat cropping system over its initial value. Hy rice-potatomaize intensive cropping system also exhibited the negative $\mathrm{N}$ balance in soil at the end of third crop cycle.

Actually, crop components of all three above mentioned crop-sequences are highly responsive to $\mathrm{N}$ application, therefore, it is possible that presently applied $\mathrm{N}$ to them was not adequate to fulfill the demands. Thus, these crop-sequences started to show negative balance of $\mathrm{N}$ in soil, but this assessment could be confirmed after some more years of experimentation.

Similar results were observed by Kharub et al., (2003), Channabasavanna et al., (2002), Narkhede et al., (2011) and Kumar, et al., (2012) also. Remaining crop-sequences did not deviate the $\mathrm{N}$ balance of soil after completion of third crop cycles over it's initial status. The status of available $\mathrm{P}$ in the soil showed a little decline over its initial value under all crop-sequences except to ricevegetable pea -sunflower and it was also true for $\mathrm{K}$ in all crop-sequences. However, differences in available $\mathrm{P}$ and $\mathrm{K}$ status of soil as influenced by different crop-sequences were not significant.

\section{References}

Adisarwaranto, T., Kuntyastuti, H. and TaufiK, A. (2002). Legumes in tropical rice - based cropping systems in Indonesia (in) Ramakrishna et al., Legumes in rice - based cropping systems in tropical Asia constraints and opportunities, PP. 26-41.

Baishya, A., Gogoi, Bhabesh, Hazarika, J., Hazarika, J.P., Bora, A.S., Das, A.K., Borah, M. and Sutradhar, P. (2016). Maximizing system productivity and profitability through crop intensification and diversification with rice (Oryza sativa)- based cropping systems in acid soils of Assam. Indian Journal of Agronomy, 61 (3) : 274-280.

Channabasavanna, A.S., Itnal, C.J. and Patil, S.G. (2002). Productivity economic analysis and changes in physic-chemical properties of soil as influenced by integrated rice (Oryza sativa)-based farming systems. Indian Journal of Agronomy, 47 (1) : 1-5.

Chitale, Shrikant, Sarawgi, S.K., Tiwari, Alok and Urkurkar, J.S. (2011). Assessment of productivity and profitability of different rice (Oryza sativa) based cropping systems in Chhattisgarh plains. Indian Journal of Agronomy, 56 (4) : 305-310.

Hedge, D.M., Prakash, Tiwari, S. and Rai,M.2003.Crop diversification in Indian agriculture. Agriculture Situation in India 8 :255-272.

Kachroo, Dileep, Thakur, N.P., Kour, 
Manpreet, Kumar, Parshottam, Sharma, Rohit and Khajuria, Vijay (2014). Diversification of rice (Oryza sativa)based cropping system for enhancing productivity and employment. Indian Journal of Agronomy, 59(1) : 21-25.

Khanda, C.M., Mandal, B.K. and Garnayak, L.M. (2005). Effect of integrated nutrient management on nutrient uptake and yield of component crops in rice (Oryza sativa)- based cropping systems. Indian Journal of Agronomy, 50(1): 1-5.

Kharub, A.S., Chouhan, D.S., Sharma, R.K., Chhokar, R.S. and Tripathi, S.C. (2003). Diversification of rice - wheat system for improving soil fertility and productivity. Indian Journal of Agronomy, 48(3) : 149-152.

Kumar, Alok, Tripathi, H.P. and Yadav, R.A. (2012). Intensification and diversification in rice (Oryza sativa)wheat (Triticum aestivum) cropping system for sustainability. Indian Journal of Agronomy, 57(4) : 319-322.

Narkhede, W.N., Deshmukh, M.S., Bhale, V.M., Gill, M.S., Gadade, G.D. and More, S.S. (2011). Diversification of cropping systems under assured irrigation conditions in central plateau zone of Maharashtra. Indian Journal of Agronomy, 56(2) : 104-108.

Paiboonrath, P., Chiemchaisti, Y., Baimuang, S. and Sukuntament, N. (2001). Legumes in rice -based cropping system in Thailand - (IN) Ramakrishna et al., legumes in rice - based cropping system in tropical Asia, constraints and opportunities. pp. 97-110.

Sharma, R.P., Pathak, S.K., Haque, M. and Lal, manser (2008). Productivity, profitability and nutrient balance as influenced by diversification of rice (Oryza sativa)- wheat (Triticum aestivum) cropping system, Indian Journal of Agronomy, 53(2): 97-101.

Sharma, S.K. and Sharma, S.N. (2002). Balance sheet of nitrogen, phosphorus and potassium under different rice (Oryza sativa)-based cropping systems. Indian Journal of Agronomy, 47 (1): 611.

Singh, G., Mehta, R.K. and Singh, R.V. (2001). Energetics, yield, water use and economics of rice (Oryza sativa) - based cropping system in flood-prone situation of eastern Uttar Pradesh. Indian Journal of Agronomy, 46 (4): 578-583.

Singh, Dinesh Kumar, Singh, Rohitashav, Singh, Gaurav Deep, Singh, Ajit Pratap, Chaturvedi, Sumit and Rathi, Amarjeet (2016). Influence of rice (Oryza sativa)wheat (Triticum aestivum) system diversification on productivity and profitability under Garhwal Himalayan region. Indian Journal of Agronomy, 61 (4): 425-428.

Singh, R.D., Sikka, A.K., Shivani and Rajan, K. (2008). Effect of irrigation and nitrogen on yield, water use efficiency and nutrient balance in rice (Oryza sativa)-based cropping system. Indian Journal of Agricultural Sciences, 78 (1): 21-26.

\section{How to cite this article:}

Vikas Jain and Kushwaha. H. S. 2020. Influence of Rice (Oryza Sativa) Based System Diversification on Yield Attributes of Rice, Productivity, Water Economics, Uptake of Nutrients and Soil-Health. Int.J.Curr.Microbiol.App.Sci. 9(03): 1363-1372. doi: https://doi.org/10.20546/ijcmas.2020.903.158 